\title{
Evaluation on Innovation Ability of Innovative City of Science and Technology
}

\author{
Jinbang Zhang \\ Department of management science \\ Bozhou Vocational and Technical College \\ Bozhou, China \\ e-mail: apaqizhang@126.com
}

\author{
Yanping $\mathrm{Fu}$ \\ Chinese Teaching Group \\ Bozhou Road East School \\ Bozhou, China \\ e-mail: fuyp521@163.com
}

\begin{abstract}
This paper aims at the research into evaluation on innovation ability of innovative city of science and technology. Firstly, it defines the connotation of innovative city of science and technology, and it builds the evaluating indicator of innovation ability of innovative city of science and technology from four aspects, including technical innovation human resources, technical innovation environment, technical innovation input and technical innovation output. Secondly, it builds the model of evaluation on innovation ability of innovative city of science and technology by the factor analysis theory, and puts forward "technology index of city' innovation ability" to evaluate the ability of innovative city of science and technology. Lastly, we choose seven cites, including. Beijing, Shanghai, Tianjin, Wuhan, Guangzhou, Nanjing, Xi'an, to make an overall evaluation on their innovation ability.
\end{abstract}

Keywords- innovative city of science and technology; innovation ability; factor analysis; evaluation

\section{INTRODUCTION}

Innovation has become a decisive factor of a city's comprehensive competitiveness. So, the evaluation on cities' innovation ability is well worth studying, the existing evaluation on cities' innovation ability is for the general cites, it does not apply to different types of evaluation on cities' innovation ability. According to the content of innovation activities which focus on different aspects, the domestic theory circle segments innovation cities into four types, technology type, service type, culture type, and industry type [1].

Science and technology is increasingly making great contribution to the development of economy, scientific and technological innovation becomes the important factor to promote the growth of regional economies. This paper makes a scientific and reasonable research on scientific and technological innovation cities, which makes it more pertinent and applicable, and it can also remedy a defect which brought by the common research on cities' innovation ability without segmenting them into different types of cities so it provides an important basis for the scientific evaluation on innovation ability of scientific and technological innovation cities.
II. THE CONNOTATION OF INNOVATIVE CITY OF SCIENCE AND TECHNOLOGY AND THE EVALUATION INDEX SYSTEM OF INNOVATION CAPABILITY

\section{A. Selecting a The connotation of innovative city of science and technology}

In the past, from the angle of innovation -driven economy, the connotation of "innovative city" which was put forward from western country is the main meaning, it mainly studies the model of economic growth and urban economic development which was driven by innovation , and increasingly integrate the idea and thought of social development [2]. In China, Jinwulun (2006) believes that innovative city, with its continuous innovation, is able to promote the whole city to achieve the great economic and social development in the area of new technical breakthrough and industrial basis, to fundamentally change the original of the mode of economic growth, to adjust the economic structure radically, and improve its international competitiveness at a high level [3]. From the angle of systematology, "creative city" refers to the creative solution offered when city faces some problems .which can bring the city activity, these issues include : Traffic management industry development urban environment and racial integration and so on [4]. In China, Duruy (2006) considers innovative city is not just technological progress and innovation of science, it covers a innovation system of city, which includes technical innovation, organizational innovation, institutional innovation, financial innovation, marketing innovation, and so on, it is also an important way and key measures to realize the leaping development of the city [5].

In the past, the foreign lacks study on innovative city of science and technology, in China, there is little study on such city. From the angle of scientific and technological innovation, Xiangdashun, Yangshenghui(2009) consider that innovative city of science and technology is that innovative environment is optimized continuously, innovative mechanism is perfect, innovative resource is integrated at a high level, spirit of innovation is vigorously promoted, qualified scientists and technicians emerge increasingly, The subject of innovation is fully activated, scientific and technological innovation becomes the leading force in the economic and social development, achievement of scientific and technological innovation benefit the modern city with the broad masses [6]. From the point of innovative system, 
Pengshunchang, Libo(2009)think innovative city of science and technology is that technology depends no more than $30 \%$ on outside, the scientific and technological progress contribution to development of economy exceeds $70 \%$, the amount of patent for invention accounts more than $70 \%$ in the total number of patent, the patent in enterprise accounts for the vast majority of the total number of patent in the whole society , about more than $70 \%$,the investment of R\&D accounts for more than 3\% in GDP, and the investment of $\mathrm{R} \& \mathrm{D}$ in enterprise is $4 \%$ more than sales income. Besides the hard-and-fast standard above, innovative city of science and technology should have a good innovative system and policy, strong technology strength, a high quality of public service platforms, and a strength of the innovative business ventures, which can create sound industrial agglomeration, offers effective allocation of resources, promote innovation of advanced culture, and attaches great importance to regional and international cooperation [7].

Combines scholars' point of view, this study will give innovative city of science and technology a basic connotation: it is a city development model in the new economic conditions, with personnel and technology as the driving force ,mainly on the basis of innovative input and environment of science and technology, scientific and technological innovation has become a decisive factor of city's comprehensive competitiveness, achieved great development of economy and city, it is also a city with strong economic, high and new technology companies gathering, many research institutions, and advanced education. This definition contains following meaning:

(1) human resources is the key of innovative city of science and technology. (2) scientific and technological innovation is the core of innovative city of science and technology. ( 3 ) innovative environment of science and technology is the prerequisite and carrier of innovative city of science and technology. (4) innovative input of science and technology is the basis of innovative city of science and technology.

\section{B. Evaluation indicators system of innovation ability of innovative city of science and technology}

\section{1) The principle of choosing evaluation indicators}

(1) Scientificity principle. Indicators must be made with scientific as the primary, clear and it is able scientifically reflect the intension and extension of the evaluation indicators [8].

(2) Prospective principle. The development of innovative city of science and technology is historical process of evolution , at present, the evaluation on innovative city of science and technology is a new field, and no ready-made model can be reference, this paper emphasized on idea that regards talent resources and technological innovation as the core, the indicators selected should comply with the leading development direction of innovative city of science and technology [9].

(3) Representative principle. Innovation ability of innovative city of science and technology has many indicators, each indicator has close inter relation. Therefore, in the design of indicators, we should choose the outburst, representative ones.

(4) Quantifiable principle. To get an objective evaluation results, in the design indicators, we should choose quantifiable ones.

(5) Data's availability principle. In the design of indicators, we should consider availability of data, so the data can be obtained through cities or various related statistical yearbook [10].

2) The establishment of evaluation indicators system

Based on the understanding of the connotation of innovative city of science and technology, combining the principle of choosing evaluation indicators, and through analyzing the personality and generality characteristic of innovative city and innovative city of science, this paper establishes evaluation indicators system of innovation ability of innovative city of science and technology from four aspects, including science and technology talent resources, science and technology innovation environment, science and technology input, and science and technology output, details as follows:

(1) Innovative human resources of science and technology. Human resources are the key factor for the sustainable development of the innovative city. It has played a inestimable function. Human resources mainly include the talent quality and the total; further subdivide into five other factors: in school university student population per ten thousand, in school graduate student, the proportion of the scientist and engineer account for the technological people.

(2) Innovative environment of science and technology 。 Innovative environment is the precondition of the development of the innovative city, it mainly includes infrastructure, financial environment and market environment, as being further subdivided into ten other factors such as: the user numbers of mobile phone at the end of the year, the remaining sum of personal savings deposit at the end of the year, the annual growth of the sum of import and export and so on.

(3) Investment of the science and technology innovation. It is the basis of the innovative city which mainly includes the funds investment and the institutions of technology innovation, further subdivided into eight factors such as: the proportion of R\&D expenditure account for GDP, financial education expenditure, the number of the higher education research institutions and so on.

(4) Output of the science and technology innovation. It is the new output of the science and technology innovation, it appears the ability of science and technology convert into the real productivity. It mainly includes research results and the roles played on the development of the city, as being subdivided into five factors: the numbers of patent application per ten thousand, the growth of GDP, the consumption of the city residents per capita and so on.

In order to illustrate the indicators evaluation of innovation capability, the evaluation system of the innovation city adopt four 4 higher indicators, 9 secondary indicators and 28 three levels of indicators. 
TABLE I. THE EVALUATION SYSTEM OF THE INNOVATION CITY

\begin{tabular}{|c|c|c|c|}
\hline The first & The second & The third & Unit \\
\hline \multirow{5}{*}{$\begin{array}{l}\text { Human } \\
\text { resources }\end{array}$} & \multirow{3}{*}{ Talent quality } & $\begin{array}{l}\text { In school university students } \\
\text { per ten thousand }\left(X_{1}\right)\end{array}$ & people \\
\hline & & $\begin{array}{l}\text { in school graduate student } \\
\left(\mathrm{X}_{2}\right)\end{array}$ & people \\
\hline & & $\begin{array}{l}\text { The books number of public } \\
\text { library per million }\left(\mathrm{X}_{3}\right)\end{array}$ & copies \\
\hline & \multirow{2}{*}{$\begin{array}{l}\text { The total of the } \\
\text { talent }\end{array}$} & $\begin{array}{l}\text { the proportion of the scientist } \\
\text { and engineer account for the } \\
\text { technological people }\left(\mathrm{X}_{4}\right)\end{array}$ & $\%$ \\
\hline & & $\begin{array}{c}\text { The number of technology } \\
\text { people }\left(\mathrm{X}_{5}\right)\end{array}$ & $\begin{array}{l}\text { Million } \\
\text { people }\end{array}$ \\
\hline \multirow{10}{*}{$\begin{array}{l}\text { The } \\
\text { environment } \\
\text { of innovation }\end{array}$} & \multirow{6}{*}{ infrastructure } & $\begin{array}{l}\text { The number of institutions } \\
\left(\mathrm{X}_{6}\right)\end{array}$ & $\mathrm{a}$ \\
\hline & & $\begin{array}{l}\text { the user numbers of mobile } \\
\text { phone at the end of the year } \\
\text { (X7) }\end{array}$ & $\begin{array}{c}\text { Ten } \\
\text { thousands }\end{array}$ \\
\hline & & The internet users $\left(X_{8}\right)$ & $\begin{array}{c}\text { Ten } \\
\text { thousands }\end{array}$ \\
\hline & & $\begin{array}{l}\text { The total of annual passengers } \\
\left(\mathrm{X}_{9}\right)\end{array}$ & $\begin{array}{c}\text { Ten } \\
\text { thousands } \\
\end{array}$ \\
\hline & & $\begin{array}{l}\text { The total of annual freight } \\
\qquad\left(\mathrm{X}_{10}\right)\end{array}$ & $\begin{array}{c}\text { Ten } \\
\text { thousands } \\
\text { tons }\end{array}$ \\
\hline & & $\begin{array}{l}\text { The bus numbers per million } \\
\left(\mathrm{X}_{11}\right)\end{array}$ & $\mathrm{a}$ \\
\hline & \multirow{2}{*}{$\begin{array}{l}\text { Financial } \\
\text { environment }\end{array}$} & $\begin{array}{l}\text { the remaining sum of personal } \\
\text { savings deposit at the end of } \\
\text { the year }\left(\mathrm{X}_{12}\right)\end{array}$ & $\begin{array}{l}\text { Million } \\
\text { RMB }\end{array}$ \\
\hline & & $\begin{array}{l}\text { The total of actual foreign } \\
\text { investment annual }\left(\mathrm{X}_{13}\right)\end{array}$ & $\begin{array}{l}\text { Million } \\
\text { dollars }\end{array}$ \\
\hline & \multirow{2}{*}{$\begin{array}{c}\text { Market } \\
\text { environment }\end{array}$} & $\begin{array}{l}\text { The deal contract numbers in } \\
\text { techniques market }\left(\mathrm{X}_{14}\right)\end{array}$ & item \\
\hline & & $\begin{array}{l}\text { the annual growth of the sum } \\
\text { of import and export }\left(X_{15}\right)\end{array}$ & $\%$ \\
\hline \multirow{8}{*}{$\begin{array}{l}\text { The } \\
\text { investment of } \\
\text { innovation }\end{array}$} & \multirow{3}{*}{$\begin{array}{c}\text { Funds } \\
\text { investment }\end{array}$} & $\begin{array}{l}\text { the proportion of R\&D } \\
\text { expenditure account for GDP } \\
\left(\mathrm{X}_{16}\right)\end{array}$ & $\%$ \\
\hline & & $\begin{array}{l}\text { The local technology finance } \\
\text { allocate account for the total } \\
\left(\mathrm{X}_{17}\right)\end{array}$ & $\%$ \\
\hline & & $\begin{array}{l}\text { The local education finance } \\
\text { allocate }\left(\mathrm{X}_{18}\right)\end{array}$ & $\begin{array}{l}\text { Million } \\
\text { RMB }\end{array}$ \\
\hline & \multirow{5}{*}{$\begin{array}{l}\text { Institutions of } \\
\text { technology } \\
\text { innovation }\end{array}$} & $\begin{array}{c}\text { The total of High-tech } \\
\text { enterprises in development } \\
\text { area }\left(\mathrm{X}_{19}\right)\end{array}$ & $\mathrm{a}$ \\
\hline & & $\begin{array}{c}\text { Large and middle scale } \\
\text { Industrial enterprise research } \\
\text { number }\left(\mathrm{X}_{20}\right)\end{array}$ & a \\
\hline & & $\begin{array}{c}\text { Number of scientific research } \\
\text { institutions }\left(\mathrm{X}_{21}\right)\end{array}$ & $\mathrm{a}$ \\
\hline & & $\begin{array}{l}\text { The research site numbers for } \\
\text { after Dr. }\end{array}$ & $\mathrm{a}$ \\
\hline & & $\begin{array}{l}\text { Numbers of the key laboratory } \\
\text { of state }\left(\mathrm{X}_{23}\right)\end{array}$ & $\mathrm{a}$ \\
\hline \multirow{5}{*}{$\begin{array}{l}\text { Out of the } \\
\text { innovation }\end{array}$} & \multirow{2}{*}{$\begin{array}{l}\text { Output of } \\
\text { research }\end{array}$} & $\begin{array}{c}\text { numbers of patent application } \\
\text { per ten thousand }\left(\mathrm{X}_{24}\right)\end{array}$ & item \\
\hline & & $\begin{array}{l}\text { Authority for patent per ten } \\
\text { thousands }\left(\mathrm{X}_{25}\right)\end{array}$ & item \\
\hline & \multirow{3}{*}{$\begin{array}{l}\text { Development } \\
\text { of the } \\
\text { economic and } \\
\text { city }\end{array}$} & Location GDP growth $\left(\mathrm{X}_{26}\right)$ & $\%$ \\
\hline & & $\begin{array}{c}\text { Comprehensive energy } \\
\text { consumption per ten } \\
\text { thousands RMB }\left(\mathrm{X}_{27}\right)\end{array}$ & $\begin{array}{l}\text { Tons of } \\
\text { standard } \\
\text { coals } \\
\text { per } \\
\text { million } \\
\end{array}$ \\
\hline & & $\begin{array}{l}\text { The consumption of city } \\
\text { residents per }\left(X_{28}\right)\end{array}$ & $\begin{array}{l}\text { Million } \\
\text { per year }\end{array}$ \\
\hline
\end{tabular}

\section{THE EVALUATION MODEL OF THE INNOVATION ABILITY OF THE TECHNOLOGY INNOVATION CITY}

\section{A. The mathematical model of factor analysis}

Factors analysis method is a multivariable variable statistical analysis method which embarks from the interior related dependence of the variable and sums up some complex relations' variable as the minority several comprehensive factors, this comprehensive variable can reflect most of the message which the original all factors have, in this way, the data structure has been simplified and we call this minority several comprehensive variables, the factor.

Hypothesis, there are $\mathrm{N}$ original variables such as $x_{1}, x_{2}, x_{3}, \ldots, x_{n}$, and $\mathrm{M}$ factors such as $f_{1}, f_{2}, f_{3}, \ldots, f_{m}(m<n)$, based on the request of factor analysis, we assume several variables have been standardized (average is 0 , Standard deviation is 1 ), so the mathematical model of factor analysis is [11]:

$$
\begin{aligned}
& x_{1}=a_{11} f_{1}+a_{12} f_{2}+a_{13} f_{3} \ldots \ldots+a_{1 m} f_{m}+\varepsilon_{1} \\
& x_{2}=a_{21} f_{1}+a_{22} f_{2}+a_{23} f_{3} \ldots \ldots+a_{2 m} f_{m}+\varepsilon_{2} \\
& \ldots \ldots \ldots \ldots \ldots \ldots \ldots \ldots \ldots \ldots \ldots \ldots \ldots \ldots \ldots \ldots \ldots \ldots \ldots \ldots \ldots \ldots \ldots \ldots \ldots \ldots \ldots \ldots \ldots \ldots \ldots \ldots \ldots \ldots \\
& x_{n}=a_{n 1} f_{1}+a_{n 2} f_{2}+a_{n 3} f_{3} \ldots \ldots . .+a_{n m} f_{m}+\varepsilon_{n}
\end{aligned}
$$

The matrix style is $X=A F+\mathrm{E}$. $\mathrm{X}$ is the original variable vector, $A$ is a public factor loaded factors for the matrix, $F$ is a public factor vector, $\mathrm{E}$ is a special vector. $a_{i j}$ meanings that the explain degree from the public factor $j$ to the original variable $i, \varepsilon_{n}$ is a special factor, explain the part of the original variable which can not been explained by factors, usually this part is so small that can be ignored.

\section{B. Establish the evaluation model of the technology city innovation ability}

The article based on the mathematical model of factor analysis and established the model such as the following:

$$
F=\sum_{j=1}^{m} f_{j} \cdot d_{j}
$$

$f_{j}$ is the main factors' score, ${ }^{d}$ is the contribution of factors, $\mathrm{F}$ is the Comprehensive score of technology innovation city and in this article we call it "the technology index of the capacity which cities can create", we use it to evaluate the cities' innovation capacity.

Specific evaluation steps are:

Main factors score. Based on the formula $f_{j}=\sum_{j=1}^{m} a_{i j}{ }^{\prime} \cdot x_{i j}$

and compute the score of every main factor have, the $a_{i j}$ is the coefficient, ${ }^{X_{i j}}$ is the date has been standardized. 
Compute the comprehensive score of every city. Based on the formula $F=\sum_{j=1}^{m} f_{j} \cdot d_{j}$, we use the value $d_{j}$ which come form the other factors' party's contribution ratio to compute the comprehensive score and $d_{j}=\lambda_{j} / \sum_{j=1}^{m} \lambda_{j}, \lambda_{j}$ is characteristic value of relative matrixes), at the end, we do a ranking by the final scores.

\section{INSTANCE ANALYSIS}

Based on the connotation of technology innovation city and the evaluate indicators system have been established, the article have select BeiJing, ShangHai, TianJin, WuHan, GuangZhou, NanJin, Xi'an , using the SPSS16.0 software to analysis and statistics, at last,we can validate the feasibility and rationality of this Indicators system and the evaluate model.

(1)To obtain and process data. The related data source come from Chinese statistics annual (2009), Chinese technology statistics annual (2009), Chinese city statistics annual (2009), Cities statistics annual. In order to eliminate the influence created by standardized indicators and make the indicators can be compared easily; we should do a standardized process to the original data.

(2)Extract the main factor variable. We should establish related coefficient matrix based on the indicators data and get the corresponding results at last. Based on the rules that characteristic value is big than 1 and total of party's contribution is big than $85 \%$, the article extract 4 factors as the main factors.

TABLE II. THE CHARACTERISTIC VALUE AND TOTAL OF PARTY'S CONTRIBUTION \% OF THE FACTORS

\begin{tabular}{|c|c|c|c|}
\hline \multirow[b]{2}{*}{ NO } & \multicolumn{3}{|c|}{ The factor before turning } \\
\hline & $\begin{array}{c}\text { characteristic } \\
\text { value }\end{array}$ & party's contribution \% & $\begin{array}{l}\text { total of party's } \\
\text { contribution \% }\end{array}$ \\
\hline 1 & 16.318 & 58.279 & 58.279 \\
\hline 2 & 5.731 & 20.469 & 78.748 \\
\hline 3 & 2.844 & 10.157 & 88.905 \\
\hline 4 & 1.835 & 6.552 & 95.458 \\
\hline 5 & .854 & 3.049 & 98.507 \\
\hline 6 & .418 & 1.493 & 100.000 \\
\hline 7 & $9.038 \mathrm{E}-16$ & $3.228 \mathrm{E}-15$ & 100.000 \\
\hline \multirow[t]{3}{*}{$\vdots$} & $\vdots$ & $\vdots$ & $\vdots$ \\
\hline & \multicolumn{3}{|c|}{ The main factor extracted after turning } \\
\hline & $\begin{array}{c}\text { characteristic } \\
\text { value }\end{array}$ & party's contribution \% & $\begin{array}{l}\text { total of party's } \\
\text { contribution \% }\end{array}$ \\
\hline
\end{tabular}




\begin{tabular}{|c|c|c|c|}
\hline GuangZhou & -0.63274 & -0.45175 & 1.416823 \\
\hline NanJin & -0.12648 & -0.21756 & -1.53151 \\
\hline WuHan & 0.042264 & -0.62714 & -1.04429 \\
\hline Xi'an & -0.33413 & -1.07869 & 0.296478 \\
\hline city & $f_{4}$ & $\begin{array}{c}\text { Technology } \\
\text { index of city } \\
\text { innovation } \\
\text { ability }\end{array}$ & $\begin{array}{c}\text { Comprehensive } \\
\text { order }\end{array}$ \\
\hline BeiJing & -0.17366 & 83.18257 & 1 \\
\hline ShangHai & 0.062212 & 62.68401 & 2 \\
\hline TianJin & -1.17943 & -29.62102 & 5 \\
\hline GuangZhou & 1.51801 & -0.53189 & 3 \\
\hline NanJin & 1.093677 & -23.22768 & 4 \\
\hline WuHan & -0.34247 & -38.59273 & 6 \\
\hline Xi'an & -0.97833 & -53.89282 & 7 \\
\hline As the & 3, Beining & first \\
\hline
\end{tabular}

As the table 3, BeiJing is the first because it is the capital of china and it is the center of political, economic, cultural and information, large numbers of significant colleges and scientific research institutions are located here. The second is ShangHai, as the biggest city in mainland china, it is the center of economic, financial and trade, it owns the biggest industrial base. After them by order are: GuangZhou, NanJin, TianJin, WuHan and Xi'an.

\section{CONCLUSION}

The article establish the evaluation model by factor analysis method and get the method of how to evaluate the ability of technology innovation city. So we get the conclusion: (1) it has provided important evidence for the ability evaluating through the scientific and reasonable research of the technology innovation ability. (2) In order to compensate the inadequate of research brought by don't distinguish the special and general style before, the evaluation model proposed in this article give us a special purpose and applicability to evaluate the ability of technology innovation city. (3) The great advantages of factor analysis method is that it based on the relation of different indicators and the degree of difference to determine the value, it can reflect the reality relations between different facts and avoiding the deviation brought by subjective element . So it is a scientific and useful method to evaluate the innovation ability of technology innovation city by factor analysis method.

\section{REFERENCES}

[1] Jin Chen improve the innovation ability independent, construct the innovative city research in HangZhou.ZheJiang Zhejiang university, 2007.

[2] S. James. Innovative cities [M]. London \& New York: Spon Press, 2001.

[3] Wulun Jin and Jinde Li,Yan, how to be the first innovative city in BeiJing. The front vol. 2, pp. 43-45, 2006.

[4] C. Landry.The Creative City: A Toolkit for Urban Innovators [M]. London: Earthscan Publications, 2000.

[5] Hui Du, the connotation and features of innovative cities. DaLian Cadres Publications, vol. 22, pp. 10-12, 2006.

[6] Dashun Xiang and Shengjun Yang, the appeared problems when constructing the innovative city in Xiang Tan and the corresponding solution. Xiang Tan teach college publications. ( natural science) vol. 31, pp. 146-148,2009.

[7] Shunchang Peng and Bo Li, The research of the index of evaluation the technology innovative city. Xia Men technology, 2009.

[8] Jie Zhang and Kewei Liu, Evaluation on innovation ability of the main cities in china. Technology Research.2007, 11.

[9] Dongmei Yang. Research on theory and testament in innovative city. Tian Jin university, 2006.

[10] The networks of the city development in china. The index system of evaluation on innovation ability of city. BeiJing 2009, the report of cities' innovation in china.

[11] Taozhu Feng and Xiaofeng Li. The evaluation of technology innovation ability in Shan Xi based on factors analysis. Technology and Management. vol. 29, pp. 221-224,2008. 